\title{
Диференційний потенціал автологічних стовбурових мезенхімальних клітин за умов інтактного мозку
}

\author{
V. I. TSYMBALIUK ${ }^{1}$, I. I. TORIANYK ${ }^{2}$, V. V. KOLESNYK ${ }^{1}$
}

Institute of Neurosurgery by A. P. Romodanov of the NAMSU1

SH "Institute of Microbiology and Immunology by I. I. Mechnykov of the NAMSU"2

\section{DIFFERENTIAL POTENTIAL OF AUTOLOGOUSSTEM MESENCHYMAL CELLS IN CONDITIONS OF THE INTACT BRAIN}

\begin{abstract}
Метою представленої роботи було визначити диференційний потенціал автологічних стовбурових мезенхімальних клітин (АСМК) в умовах інтактного головного мозку. Всі процедури відтворені в експерименті на самцях щурів лінії Вістар тримісячного віку масою 160-175 г. Спостереження тривалістю 14 діб супроводжувались поступовим (1-ша, 3-тя, 7-ма, 14-та доби) виведенням тварин із дослідів (передозування амфітамінового наркозу). Аналіз отриманого матеріалу $(\Sigma=60)$ проводили із застосуванням класичних гістологічних, імуноцитохімічних, люмінесцентних методів (забарвлення зрізів гематоксиліном та еозином, залізним гематоксиліном за Рего, імпрегнацією азотно-кислим сріблом за Кахалем, за Ніслем). Встановлено, що застосування АСМК на інтактному головному мозку призводить до появи гліомезодермальних клітин, однак не сприяє нейро- та синапсогенезу. Невід’ємну за цим сценарієм ініціацію неоангіогенезу спонукають фактори експериментального хірургічного втручання, яке супроводжує кожен із заявлених способів трансплантації клітин. Отримані авторами дані можуть застосовуватись як уніфіковані стандарти порівняльного контролю в експериментах з трансплантації стовбурових клітин.

The purpose of the present work was to study differential potential of autologous stem mesenchymal cells (ASMC) in conditions of the intact brain. All procedures were carried out in an experiment on 3-month-old intact male Wistar rats weighing 160-175 g. The observations lasted 14 days, the animals were gradually (on the $1^{\text {st }}, 3^{\text {rd }}, 7^{\text {th }}$ and $14^{\text {th }}$ days) taken out of the experiments (overdosage of amphetamine anaesthesia). The obtained material was analysed by the use of classical histological, immunocytochemical and fluorescence methods (staining of sections with haematoxylin and eosin, with iron hematoxylin by the Regaud method, impregnation with silver nitrate by the Cajal and Nissl methods). It was found out that the use of ASMC on the intact brain resulted in the appearance of gliomesodermal cells, but did not contribute to neuro- and synapsogenesis. The initiation of neoangiogenesis, which was an integral component in compliance with the above scenario, was caused by factors of an experimental surgical intervention, the latter accompanying each of the ways (intracranial, intravenous, suboccipital) used for transplantation of stem cells. The authors' findings can be applied as uniform standards for comparative control in experiments with stem cell transplantation.
\end{abstract}

Постановка проблеми і аналіз останніх досліджень та публікацій. Сучасна медицина переживає період широкого впровадження новітніх лікувальних технологій. Серед останніх живу зацікавленість спеціалістів різних галузей (в тому числі й нейрохірургів) викликає застосування клітинної трансплантації [1, 3, 10]. Найбільш вживаним у зазначеному сенсі матеріалом є стовбурові клітини (зокрема, мезенхімальні автологічні). Їхня ефективність у стимуляції відновних реакцій, що відбуваються на тлі деструктивно-дегенеративних процесів, некрозу, не викликає жодного сумніву [11]. Однак, механізми реалізації цілої низки ефек- тів, найбільш прийнятні способи введення останніх, специфіка вибору експозиційних строків, тривалість лікувальних процедур на сьогодні потребують подальшої розробки [9, 12]. Безліч дискусій викликають результати застосування стовбурових клітин на тлі інтактних органів (головний, спинний мозок тощо). Відкритими залишаються питання щодо структурно-фізіологічної реакції нервової тканини на появу стовбурових клітин, “контактна торпідність” нейронів у відповідь на трансплантацію автологічних стовбурових мезенхімальних клітин (АСМК). Ретельного аналізу потребують питання, пов'язані із розшифруванням та подальшим тлума- 
ченням типологічної домінанти так званих “епітеліоподібних" клітин. Постає проблема визнання ролі та місця гліомезодермоцитів, - чи то як попередників певних структур неогенезу, чи то як його завершальний варіант. Отже, в цілому вивчення диференційного потенціалу АСМК за умов інтактного мозку - актуальне завдання біології та медицини, що доволі далеке від свого остаточного розв'язання.

Матеріали і методи. Матеріалом експериментального дослідження стали самці щурів лінії Wistar ( $\mathrm{n}=60)$, тримісячного віку, масою 160-175 г. Метою експерименту було визначення диференційного потенціалу автологічних стовбурових мезенхімальних клітин (АСМК) в умовах інтактного головного мозку. За цим застосовували 3 способи введення (внутрішньовенний (BВ), інтракраніальний (IK), субокципітальний (СО)) суспензії АСМК у 0,1 мл культурального середовища (KC) у дозі $3,5-5 \times 10^{5}$. Трекінг клітин спостерігали протягом 14 діб [4, 5]. Хірургічне втручання проводили стандартно. Щурів наркотизували інтраперитонеально (із розрахунку 125 мг на 1 кг маси) амфітаміновим наркозом, потім вводили суспензію АCMK через v. caudate, cysterna occipitalis та на facies corticalis lobulus paracentralis cerebri [2]. Вищезазначені заходи стосувались тварин експериментальних груп (BВ, IK, CO $\left.\left(\sum=36\right)\right)$, а також групи порівняльного контролю (ПК, $n=12$ ), особинам якої трьома вищезазначеними способами вводили виключно КС. Групу інтактного контролю (IK) становили щури (n=12), до яких не застосовували жодної із процедур та які відповідно до ветеринарного status objectives являли собою цілком здорових особин. Отримані в експерименті клітини фенотипували із застосуванням негативних (CD19, CD34, CD45) та позитивних (CD73, CD90, CD105) маркерів. Диференціювали у нейрональному напрямку 3 використанням ретиноєвої кислоти. Для забарвлення застосовували прижиттєвий флуорохром РКН 26 [6]. Перед застосуванням АСМК проводили перевірку здатності цих клітин експресувати характерні їм поверхневі маркери. Для оцінки диференціювання застосованих клітин використовували стандартні імуноцитохімічні методики. За їх допомогою виявляли наявність специфічних білків нейронів та гліальних клітин (нейроспецифічний бета-III-тубулін, нейронспецифічний нейрофіламент $200 \mathrm{kDa}$ +160 kDa, специфічний гліальний протеїн фібрил GFAP). Постмортально досліджували шматочки головного мозку (розміром $0,5 \times 0,5 \times 0,5$ см). Препарати промивали, фіксували у $12 \%$ розчині формаліну на фосфатному буфері (при $\mathrm{pH}=$ 7,0-7,2). Далі зневоднювали, заливали у смоли, виготовляли гістологічні зрізи. Останні забарвлювали азотно-кислим сріблом за Кахалем, залізним гематоксиліном та Рего, гематоксиліном та еозином. Аналіз результатів проводили відповідно до параметричних та непараметричних критеріїв. Детекція люмінесцентно мічених АСМК відбувалась за допомогою люмінесцентного мікроскопа (Lieca (Німеччина)) на гістологічних зрізах, виготовлених на кріостатному кріотомі “Bright” (Великобританія).

Результати досліджень та їх обговорення. Детальний аналіз макроструктурних особливостей інтактного головного мозку тварин, що належали до контрольної групи, свідчив на користь відповідності останніх статево-віковим показникам функціональної норми. Кожна із півкуль характеризувалась виразним рельєфом поверхні. Сіра та біла речовини залишались чітко диференційованими, без вогнищ інфарктів та некрозів. Кора великого мозку чітко диференційована, її шари (молекулярний, зовнішній, внутрішній зернисті, пірамідних клітин) добре позначені. Базовий компонент кіркової речовини належав тілам нейроцитів, пов'язаним із ними клітинам глії. Введення компонентів КС в організм контрольної групи (група порівняльного контролю) щурів лінії Вістар трьома відпрацьованими способами (BB, IK, CO) у кожен із запланованих строків (1-ша, 3-тя, 7-ма, 14-та доби) не призводило до змін у макромікроскопічній будові головного мозку. Зовнішній рельєф поверхні півкуль залишався не ушкодженим. Морфологічні зміни у півкулях, оболонках головного мозку щурів лінії Вістар даної експериментальної групи виявлялись відповідними нормо-фізіологічним статево-віковим змінам тварин зазначеної лінії. Філогенетично найбільш пізня частина кори - ізокортекс, гомогенетична кора, мала чітку за своєю диференціацією шестишарову будову. Лише в окремих ділянках кори мозку мали місце ушкодження речовини, зубчастої фасції, пов’язані з інтракраніальним операційним втручанням (поодинокі розруйновані нейрони - результат стиснення структур) та розташуванням треку ін'єкційної голки (субокципітальне введення КС). У відтермінований період (7-14-та доби) на зміну встановленим морфологічним особливостям надходили захисні реакції та процеси утилізації мізерного клітинного детриту. Інтракраніальне втручання призводило до незначних ушкоджень одного-двох поверхневих шарів кори (1-3-тя доби). На зміну останнім надходили локального характеру запальні процеси, відновлення та ліквідація наслідків клітинного розпаду (14-та доба) у місцях операційного втручання (потилична цистерна, тім'яна частка великого мозку). Мієлінові та безмієлінові волокна 
були без ознак деструкції, у разі застосування відповідного забарвлення (імпрегнація азотно-кислим сріблом за Кахалем) більш виразні, чіткі. Трансплантація АМСК в організм тварин контрольної групи, незалежно від термінів їхнього приймання (1-14-та доби спостережень) та способів введення (BB, IK, CO), не привела до критичних змін у макро- та мікроструктурі інтактного головного мозку. Поверхневий рельєф залишався незмінним. Сiра, біла речовина головного мозку контрастовані відповідно до принципів цито- та мієлоархітектоніки півкуль [3]. Однак, у відтерміновані періоди спостережень (сьома, чотирнадцята доби) відбувались процеси, які супроводжувались появою певної кількості клітин, структурно схожих на епітеліальні [4]. У зоні, симетричній трепанаційному вікну (інтракраніальний спосіб введення, 1-3-тя доби експерименту), спостерігали скупчення декількох морфологічних типів цих (полігональних) клітин зі світлими круглої, овальної, веретеноподібної форми гіперхромними ядрами, широкою, вузькою та відсутньою облямівкою цитоплазми. Осередок, що вони утворювали, відмежувався від навколишньої речовини мозку одним-двома шарами клітин з гіперхромними повздовж витягнутими ядрами. Зацікавленість цитогенетичною складовою віднайденої популяції клітин призвела до застосування якісних експертних методів [5]. Застосовані для оцінки диференціального потенціалу АСМК за наявнос-

\section{СПИСОК ЛІТЕРАТУРИ}

1. Зозуля I. С. Нейропротекторна терапія мозкового інсульту / I. С. Зозуля // Медицина неотложных состояний. - 2007. - № 5. - С. 117-119.

2. Пат. 5380 Україна, МПК G 09 В23/28 (2006.01) Спосіб моделювання гострого ішемічного церебрального інсульту у щурів / Цимбалюк В. І., Колесник В. В., Микулинський Ю. Ю., Забірник А. С., Панібратцева С. Г.; власник Харківська медична академія післядипломної освіти (ХМАПО). - № u 2010 02736; заявл. 11.03.10; опубл. 27.09. 10, Бюл. № 18.

3. Применение мезенхимальных стволовых клеток для восстановления структуры и функции поврежденных тканей и органов / И. Б. Бродский, С. А. Брянцева, О. Н. Жаппарова [и др.] // Эфферентная и физико-химическая медицина. 2011. - № 1. - C. 4-10.

4. Торяник I. І. Трекінг автологічних стовбурових мезенхімальних клітин при ішемічному інсульті у щурів / I. I. Торяник, В. В. Колесник // Світ медицини та біології. - 2015. № 1(48). - С. 167-171.

5. Торяник I. I. Алгоритм отримання аутологічних мезенхімальних клітин у експерименті / I. І. Торяник, В. В. Колесник // Вісник проблем біології та медицини. - 2015. - № 1 (117). C. 207-211. ті специфічних білків нейронів та гліальних клітин (нейроспецифічний бета-ІІІ-тубулін, специфічний гліальний протеїн фібрил GFAP), імуноцитохімічні методи викликали негативну або слабопозитивну реакцію (лише у 2-х випадках перевірки). Завдяки цьому довелось відхилити сподівання на користь ініціації нейродиференціювання АСМК за умов їхнього розосередження на поверхні інтактного мозку, з іншого боку, вдалось остаточно з'ясувати типологічне походження отриманих клітин (гліомезодермальні). Цікавим на зазначеному тлі виявився аналіз культури клітин локусів втрачених/ ушкоджених судин (проточна цитофлуорометрія з експресією стандартної панелі маркерів) [7]. Виявлений фенотип клітин демонстрував підвищення рівня негативних (ендотеліальних) маркерів на відносно сталому фоновому рівні. Тобто, ушкодження, нанесені ін'єкційною голкою під час введення суспензії клітин (в ВВ та ІК способи), фіксувались організмом та неодмінно ініціювали відновні реакції: неоангіогенез [8].

Висновки. ВВ, IK, СО способи застосування АСМК в умовах інтактного головного мозку (контрольна група щурів) in vivo не приводили до нейро- та синапсогенезу. Навколо зон ушкоджень, спричинених хірургічною ін'єкційною голкою, спостерігали осередки накопичень епітеліоподібних клітин та ознаки початкового ангіогенезу.

6. Gudas L. G. Retinoids induce stem cell differentiation via epigenetic chan-ges/ L.G. Gudas // Semin. Cell Development Biology. - 2013. - № 4. - P. 278-283.

7. Jablonska A. Stroke induced brain changes:implications for stem cell trans plantation / A. Jablonska, B. Lukomska // Acta. Neurobiol.Exp. - 2011. - Vol. 71. - P. 74.

8. Liman T. G. New vessels after stroke: postischemic neovascularization and regeneration / T. G. Liman, M. Endres // Cerebrovasc. Dis. - 2012. - Vol. 33. -P. 492-499.

9. Lindvall O. Stem cell research in stroke: how far from the clinic? / O. Lindvall, Z. Kokaia // Stroke. - 2011. - Vol. 42. P. 2369-2375.

10. Miller R. H. Translating stem cell therapies to the clinic / R. H. Miller, L. Bai // Neurosci. Lett. - 2012. - Vol. 519. - P. 87-92. 11. Safety of Cell Therapy with Mesenchymal Stromal Cells (Safe Cell): A Systematic Review and Meta-Analysis of Clinical Trials / M. M. Lalu, L. McIntyre, C. Pugliese, D. Fergusson, B. W. Winston // Plos. one. - 2012. - Vol. 7. - P. 475-479.

12. Smith H. K The potential of stem cell therapy for stroke: is PISCES the sign? / H. K. Smith, F. N. Gavins // FASEB J. - 2012. Vol. 26. - P. 2239-2252.

Отримано 02.06.15 